Euskal ikerketen aldizkaria | Revue d'études basques |

Revista de estudios vascos | Basque studies review

$13 \mid 2009$

Numéro XIII

\title{
Person restrictions in Basque intransitives
}

\section{Milan Rezac}

\section{OpenEdition \\ Journals}

\section{Electronic version}

URL: http://journals.openedition.org/lapurdum/2172

DOI: 10.4000/lapurdum.2172

ISSN: 1965-0655

\section{Publisher}

IKER

\section{Printed version}

Date of publication: 1 February 2009

Number of pages: $305-322$

ISBN: 978-2-86781-409-X

ISSN: $1273-3830$

\section{Electronic reference}

Milan Rezac, «Person restrictions in Basque intransitives », Lapurdum [Online], 13 | 2009, Online since 15 April 2013, connection on 02 May 2019. URL : http://journals.openedition.org/lapurdum/2172 DOl : 10.4000/lapurdum. 2172 


\title{
Person restrictions in Basque intransitives
}

\author{
Milan Rezac \\ CNRS UMR 7023
}

\begin{abstract}
:
I discuss the extension of the Person Case Constraint analysis of 1/2:NOR-NORI-NORK gaps (*eraman naiozu) to 1/2:NOR-NORI gaps (hurbiltzen/*gustatzen natzaio). According to it, all and only datives c-commanding a $1^{\text {st }} / 2^{\text {nd }}$ person absolutive block its agreement. Three aspects of this hypothesis are examined: (i) differences with morphological gaps, found in western varieties for all $1 / 2$ :NOR-NORI forms; (ii) coverage across the diversity of NOR-NORI structures, notably complex ones and detransitivisations; (iii) tension with the applicative agreement morphology of nonapplicative datives.
\end{abstract}

\section{Résumé:}

Je discute de l'extension de l'analyse des lacunes 1/2:NOR-NORI-NORK (*eraman naiozu) par la Contrainte sur la Personne et le Cas aux lacunes 1/2:NOR-NORI (hurbiltzen/*gustatzen natzaio). Selon cette analyse, l'accord avec la $1^{\text {ierre }} / 2^{\text {ième }}$ personne absolutive est bloqué par, et seulement par, un datif qui le c-commande. Trois aspects de cette hypothèse sont examinés: (i) son contraste avec celle des lacunes morphologiques, qui éliminent de certaines variétés toute forme 1/2:NOR-NORI; (ii) sa validité à travers la gamme des structures NOR-NORI, notamment les structures complexes et les détransitivisations; et (iii) la tension ainsi créée avec l'accord applicatif engendré par les datifs non applicatifs.

Keywords / Mots clés: agreement / accord, applicatives / applicatifs, Person Case Constraint.

\section{Two types of nor-nori verbs}

Basque transitives are subject to the restriction that $1^{\text {st }} / 2^{\text {nd }}$ person absolutive object agreement cannot co-occur with dative agreement (1). Since absolutives must agree in finite clauses, $1^{\text {st }} / 2^{\text {nd }}$ person absolutives are banned here entirely. By contrast, dative agreement, while normally obligatory in most dialects, can be suspended in precisely this context, for many speakers. ${ }^{2}$ Bonet (1991) demonstrates that relevantly identical patterns are found cross-linguistically, as in French (2) and Spanish (3), and names the restriction the Person Case Constraint or PCC.

(1) a. Zuk poliziari ni eraman *n(a)iozu / \%nauzu. (Artiagoitia 2000: 405)

b. Zuk poliziari haiek eraman dizkiozu.

1. Many thanks to P. Albizu, R. Etxepare, B. Fernández, M. Jouitteau, J. Manterola, J. Ormazabal, B. Oyharçabal for discussion, to M. Duguine for patience, and to the organizers of the Aldaketak, aldaerak, bariazioak meeting for the opportunity to talk and to listen. This work is partly funded by MEC grant FFI 2008-00240.

2. Cf. Lafitte (2001: \$574), Albizu (2001), Artiagoitia (2000), Oyharçabal and Etxepare (forthc). As in Romance, suspension seems limited to lexical datives, not e.g. possessors (Postal 1990, Bonet 1991; see Rezac 2009). 
(2) a. Vous la (luil avez présenté (*à ellel. b. Vous me (*luil avez présenté là elle).

(3) a. * (Sel la recomendaron la éll. b. Me $(* l e)$ recomendaron a él.

Several syntactic approaches to the PCC build on the following common core: the dative blocks a syntactic dependency for [person], that is [person] Agree, between a DP and a functional head, say $v$ or $\mathrm{T}$. The blocking itself is proposed to arise because the dative is a locality intervener for [+person] Agree on the $v$-ABS/ACC path (Anagnostopoulou 2003), because it occupies [Spec, $v$ P] and a spec-head configuration is needed for [person] Agree (Baker 2008), or because both the dative and the DP compete for [person] Agree with the same head to be licensed (Adger and Harbour 2007). Number agreement is unaffected, for example because the dative's [number] is invisible or has been moved out of the $v$-DP path.

(4)

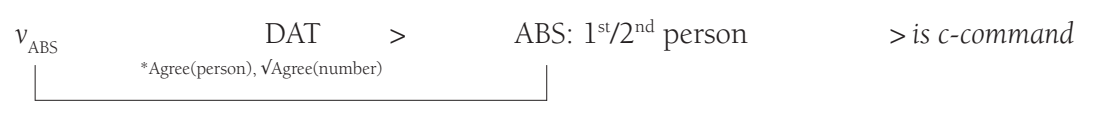

Applying the idea to Basque transitive clauses, under the Bobaljik-Laka approach to ergativity and the applicative analysis of the agreeing dative in Elordieta (2001), we see from $/(5)$ that the dative should block [+person] Agree between the absolutive assigner $v_{\mathrm{ABS}}$ and its theme goal. The nonagreeing dative of (1)a should then originate below rather than above the theme, and we return to this later.

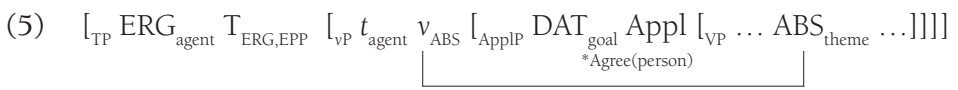

Albizu (1997) observes that some unaccusatives with an agreeing dative, that is the NOR-NORI agreement paradigm, also do not tolerate $1^{\text {st }} / 2^{\text {nd }}$ person absolutives, while others $\mathrm{do}^{3}$.

(6) a. Ni Peruri hurbildu natzaio.

[1:ABS-3:DAT]

b. Pello Mireni baldarra iruditu zaio.

[3:DAT-3:ABS]

c. Mireni gozokiak gustatzen zaizkio.

[3:DAT-3:ABS]

d. */??Ni Mireni baldarra iruditu natzaio.

[3:DAT-1:ABS]

e. */??Ni Mireni gustatzen natzaio.

[3:DAT-1:ABS] (Albizu 1997: 21)

(7) a. Ni Kepari etortzen / * gustatzen nako

[3:DAT-1:ABS]

b. Igandetan joaiten nako bisita baten egitera.

[3:DAT-1:ABS] (MD, Hazparne)

3. The contrasts can be inferred from literature such as Axular's Gero or Elizen Arteko Biblia (cited book : verse), in both of which natzaio forms are frequent but restricted to motion verbs and the other structures examined below, and missing for gustatu, laketu, falta izan, irudi(tu), the last two frequent as NOR-NORI. These sources are used below. Not all NOR-NORI psych-like verbs naturally take $1^{\text {st }} / 2^{\text {nd }}$ person absolutives: bururatu/otu 'occur', damutu 'repent'. It is not clear what we should expect of them; it may be that $1^{\text {st }} / 2^{\text {nd }}$ persons in them occur only when metaphorically conceptualized as inanimate, in which case there might be no PCC, as for some French speakers in (i). Verbs like ahaztu 'forget', interesatu 'interest' do seem to resist 1/2:NOR-NORI. For agertu 'appear', see below.

(i) */?On ne peux pas vous leur envoyer, parce que vous êtes trop lourd. [Speaking to an artist of sending his statue to an exposition of the statues of famous painters.] (Rezac and Jouitteau in prep.) 
Albizu proposes to relate this restriction to the PCC. Since the NOR-NORI agreement paradigm is otherwise identical for all the verbs above, the PCC cannot be construed as a problem with agreement morphology (Boeckx 2000), at least here (cf. section 12). Rezac (2008a) proposes that the distinction between verbs with and without 1/2:NOR-NORI forms, like natzaio, is one between psych-verbs with a dative experiencer base-generated in an applicative structure above the theme, (18)a, and motion verbs with a dative animate goal of motion originating in a prepositional structure below the theme, $(8) \mathrm{b}$. At the level of the $v \mathrm{P}$, the mutual configuration of $v$, dative, and absolutive in psych-verbs but not in motion verbs is as for applicative transitives, and so the PCC arises only in psych-verbs.

$$
\begin{aligned}
& {\left[_{\text {TP }} \mathrm{ABS}_{\text {theme }} \mathrm{T}_{\mathrm{EPP}}\left[{ }_{\mathrm{vP}} v_{\mathrm{ABS}} \quad\left[_{\text {ApplP }} \mathrm{DAT}_{\text {experiencer }} \text { Appl }\left[_{\mathrm{VP}} \ldots t_{\text {theme }} \ldots\right]\right]\right]\right] \text { (psych Vs) }} \\
& {\left[_{T P} \mathrm{ABS}_{\text {theme }} \mathrm{T}_{\mathrm{EPP}}\left[_{\mathrm{VP}} \mathrm{v}_{\mathrm{ABS}} \quad\left[_{\mathrm{VP}} t_{\text {theme }} \ldots\left[\ldots \mathrm{DAT}_{\text {goal-of-motion }} \ldots\right]\right]\right]\right] \text { (motion VS) }}
\end{aligned}
$$

Cross-linguistically, dative $>$ absolutive/nominative unaccusatives do indeed seem to show the PCC if and only if the dative c-commands the absolutive/nominative at the point where the latter Agrees with its Case licenser, $v_{\mathrm{ABS}} / \mathrm{T}_{\mathrm{NOM}}$. Icelandic furnishes a nice illustration, $/(9)$. 'Give' can basegenerate it arguments either as DAT > theme or as theme > DAT. The higher argument becomes the subject. Only in the DAT > theme configuration does the PCC arise:

$\begin{array}{clll}\text { (9) } \begin{array}{ll}\text { a. }{ }^{*} \text { Honum } \\ \text { him.DAT }\end{array} & \text { var/varst }\left[_{\mathrm{VP}}\right. & \text { gefinn } t_{\text {honum }} & \text { pú.] } \\ \text { was.3SG/2SG } & \text { given.MSG } & \text { you.NOM } \\ \text { honum } & \text { voru }\left[_{\mathrm{VP}}\right. & \text { gefnir } t_{\text {honum }} & \text { peningarnir. }] \\ \text { him.DAT } & \text { was.3PL } & \text { given.MPL } & \text { the.moneys.NOM } \\ \text { c. Pú } & \text { varst }\left[_{\mathrm{VP}}\right. & \text { gefinn } t_{\text {pú }} & \text { honum.] } \\ \text { you.NOM } & \text { was.2SG } & \text { given.MSG } & \text { him.DAT (Schütze 1997) }\end{array}$

Within Basque, various prominence diagnostics bear out the hypothesis that psych-verbs but not motion verbs base-generate the dative above the theme, though for both, the theme ends up satisfying the EPP as the 'true subject' in obligatory control. Among the diagnostics differentiating DAT $>$ theme from theme $>$ ABS configurations is bere buru binding in $/(10)$.

(10) a. Kepari bere burua / *Kepa bere burari gustatzen zako.

b. *Kepari bere burua jiten zako (ispiluan). (Rezac 2008a)

c. Miren bere buruari mintzatu zaio. (Elordieta 2001)

Below, this proposal is explored further. First, we look at a superficially similar but perhaps profoundly different phenomenon, the total absence of $1 / 2$ :NOR-NORI forms in many varieties. Next, NOR-NORI structures other than psych and motions verbs are set against the above proposal, some integrating well, others more intransigent. Last is addressed a fundamental tension between analysing hurbiltzen natzaio as using a nonapplicative dative and its apparently applicative agreement morphology.

\section{Syntactic to morphological gaps}

This article is concerned with varieties allowing some natzaio type forms, and explaining the contrast between different NOR-NORI constructions therein. Albizu (1997) notes that western Bizka- 
ian fails to allow any 1/2:NOR-NORI combinations:
(11) a. Juntau nintzaken.
b. Pello Mireni juntau jako.
I approached them.
Pello approached to Miren (Albizu 1997)

This absence has been explicitly noted for many varieties (cf. Holmer 1961: 81). ${ }^{4}$ It holds of coastal Bizkaian (Basauri, Lekeitio, Ondarroa, but see for Bermeo below), proceeds south and east to the interior (Forua, Ermua, Antzuola; Deba watershed varieties like Oñati, Mallabi, q.v. below; Ermua and Eibar with exceptions heard among a more general absence), to the border with Gipuzkoa (Bergara, Arrasate, Otxandio, q.v. below), and its central Tolosa zone (Kepa Erdozia pc for Tolosa, Urtzi Etxebarria pc for Itsasondo; the young people in Zaldibia, where adults retain the forms), and stretches to its northwest boundary (Pasaia, Oiartzun, Fernández 2004 and Julen Manterola pc for Hondarribia). ${ }^{5} \quad$ As little as eighty years ago, these forms did exist more widely (Azkue 1923-5). Markina from that period reports both frequent use of forms like etorri nakisula, and the incipient loss of $1 / 2$ :NOR-NORI forms in the allocutive conjugation, along with rarity and hesitation in less common tense-mood combinations. The forms still seem alive and well in much of Navarra and Iparralde (Ahetze, Maya, Zuberoa, Erronkari; Maia Duguine pc for Hazparne; Etxarri-Aranaz in Ultzama, but in Ultzama itself they are lost save for outliers among old people), though some loss of certainty is sometimes reported (Beskoitze), beside graver absences (Aezkoa, Larresoro).

Albizu (1997) attributes the absence of natzaio-type forms in western Bizkaian to the PCC, and perhaps so. On the approach here, it would suffice to suppose that the applicative structure is the only one possible with all $1^{\text {st }} / 2^{\text {nd }}$ person datives (cf. Jelinek 2000). However, there is reason to suspect a different cause. Many of the affected varieties do not lack all 1/2:NOR-NORI forms. Rather, they present us with "spotty paradigms", as in Table 1, familiar from Irish agreement (Andrews 1990). In Basque varieties as in Irish ones, the extant forms range from a fairly complete paradigm with some arbitrary gaps (Zeberio, cf. Beskoitze above), to a mostly empty paradigm with some remnants (Arrasate, and radically Bergara; Larresoro lies in between).

Table 1: "Spotty" paradigms for NOR-3:NORI (all lack gu/zu/zue in past)

\begin{tabular}{|c|c|c|c|c|c|c|c|c|c|}
\hline & $\begin{array}{l}\text { Present } \\
\text { ni }\end{array}$ & $\mathrm{gu}$ & $\mathrm{zu}$ & zue & hura/haiek & $\begin{array}{l}\text { Past } \\
\text { ni }\end{array}$ & hura/haiek & $\begin{array}{l}\text { Imperative } \\
\text { zu/zue }\end{array}$ & hi \\
\hline Zeberio & ñako & gaiakos & saiakos & -- & yako/s & ñakon & yakon & --/sakios & \\
\hline Arrasate & natxako? & -- & -- & -- & jako & -- & jakon & zakixo/-xue & hakixo \\
\hline Bergara & -- & -- & -- & -- & jako & -- & jakon & -- & hakixo \\
\hline
\end{tabular}

4. Italicized names refer to dialectal grammars, descriptive or generative; see the bibliography.

5. In the Irun-Pasaia-Hondarribia region, the NOR-NORI paradigm is also adopting the forms of the NORNORI-NORK one, with or without "dative displacement": gustatzen dit / nau (Fernández 2004, Hondarribial Irun). 
Two corners of the NOR-NORI paradigm seem particularly resistant to the loss. First, sometimes 1/2:NOR-NORI forms reappear in less common tense-mood combinations. Bermeo contrasts the lonely zuri natsu(?) (natzaizu) of the present/past with conditional banakio, bazakioz, bagakioz, bazakioze; same in Oñati. This may be an effect of the rare use of the conditional, triggering a more researched level. Second, as Table 1 shows, the imperative is often the last bastion of 1/2: NOR-NORI forms. (Etor) akit, akigu, sakidas, sakigus, sakidxos (Otxandio) may be present when all else has been lost; same in Mallabi and, beside only conditional forms, Oñati. Eventually, they also vanish: "Etorri hakitt hona esaldia jende dezentek darabil. Beste formak [e.g. hakixo] oso gutxi entzuten dira" (Bergara). ${ }^{6}$

Gaps of this type are familiar from the literature on Basque, particularly 1/2:NORK-2/1:NORI-NOR combinations (Fernández 2001, Rezac 2006, Arregi and Nevins 2006), as well as elsewhere: PL of French frire, 1/2SG, 2PL of Spanish abolir (Boyé and Hofherr 2010), French clitic clusters like lui y (Rezac 2010), or the past of forgo and the past participle of stride in English (Albright 2006). Their theoretical interpretation is as morphological absences, since they are syntactico-semantically arbitrary and vary without much reason across space and time. The syntactic PCC cannot be involved here. In turn, the PCC cannot be reduced to a generalisation of these morphological gaps, precisely because it is not about morphology, where hurbiltzen/gustatzen are otherwise indistinguishable.

The same dichotomy between the PCC banning otherwise extant combinations, and a more general ban on such combinations, seems to recur across French varieties for 1/2.ACC DAT clitic sequences such as nous lui, in (18), (46) and note 2. It may be that in both languages, there is a diachronic relationship between the PCC and the morphological gaps. Arbitrary gaps arise through the uncertainty of speakers about the proper morphology of a form in a maze of possibilities, so that ride -- ridden, glide -- glided, shine -- shone leave stride -- ? unclear, or through the active observation and obeisance to the absence of certain forms (Baerman et al 2010). The PCC removes a significant core of 1/2:ABS/ACC/NOM+DAT agreement combinations. The rest of the inflectional system of Basque certainly leaves it opaque how to attach a dative onto naiz, and indeed a parade of oddities arises in the NOR-NORI domain in Basque varieties (e.g. Maya). Similarly, the French clitic system leaves it unclear how to order 1/2.ACC and DAT clitics. There may thus be a diachronic flow from syntactic to morphological gaps. This observation renders more difficult our task of disentangling the two.

\section{The variety of NOR-NORI structures}

The NOR-NORI agreement paradigm is not used only by psych and motion unaccusatives. Of the remaining NOR-NORI structures, some bear out well the expected correlation of ABS > DAT c-command and absence of the PCC: idiosyncratically NOR-NORI verbs like mintzatu 'speak', be + adjective constructions, and aspectual periphrases. Others prove more difficult, for they have natzaio type forms despite being good candidates for DAT > ABS base-generation: verbs like agertu 'appear', and especially reflexive detransitivisations. However, there are some promising possibilities for the latter type. I take each of these up in turn.

For idiosyncratically NOR-NORI verbs like mintzatu, jarraiki, for fidatu, participation in this agreement paradigm seems arbitrary and subject to great variability (e.g. Deba p. 58). They are not sub-

6. This odd aspect of the imperative perhaps finds an echo in Breton. Have is the only verb to use prefixal rather than suffixal agreement (hon-bez-o '1PL-have' vs. kar-omp 'love-1PL'), and it is susceptible to regularisation and it curiously begins with the imperative (hon-bez > (hon-)bez-omp > bez-omp) (Le Roux 1957). 
ject to the PCC, (44)a, and have ABS > DAT c-command, (10)c.

$\mathrm{Be}+$ adjective constructions that participate in the NOR-NORI paradigm are of the type zordun 'indebted' / eskerdun 'grateful' / nazkagarri 'disgusting' / leial 'faithful' / hurbil (ago) 'closer(er) / atsegin 'pleasant' + izan / egon 'be'. They permit natzaio type forms, so that atsegin izan contrasts with the closely synonymous gustatu (Etxepare 2003b).

(12) Zordun bagatzaitza ere geure Iaungoikoari. (Axular)

(13) a. zu atsegin zatzaizkio vs. ??zu neri gustatzen zatzaizkit (Etxepare 2003b: 168)

b. atsegin/* gustatzen nako.

(MD)

These constructions are good candidates for ABS > DAT c-command, as in (14), on a raising analysis of be. Similar constructions in French, être redevable / fidèle + dative (15), have long been analysed so (Kayne 1975). The dative is selected by the adjective, and may be pied-piped by its topicalisation, but as an unfocussed pronoun, it cliticizes to the matrix be.

(14) $\left[\mathrm{BE}\right.$ [theme/subject-of-predication $\left.\left.\left[_{\mathrm{AP}} \mathrm{ADJ} \mathrm{DAT}\right]\right]\right]$

(15.) a. [Azenor [lui est ... $\left[_{\mathrm{SC}} t_{\text {Azenor }}\left[{ }_{\mathrm{AP}}\right.\right.$ fidèle $\left.\left.\left.t_{\text {lui }}\right]\right]\right]$ ]

b. $\left[_{\mathrm{AP}}\right.$ Fidèle à son cheval], Azenor l'est certainement.

Transposed to Basque, the absolutive subject of Azenor leial zaio is base-generated above the dative argument of the adjective, and thus the dative is no obstacle for [person] Agree with it. ${ }^{7}$ Bere buru binding confirms the posited c-command.

(16) a. Neure buruari (ni) nazkagarri natzaio. (Ortiz de Urbina 1989: 37)

b.Kepa bere buruari / *Kepari bere burua zordun egoiten zako. (MD)

Some of these locutions might involve predicative nouns rather than adjectives, e.g. atsegin 'pleasure' / zor 'debt' + NOR-NORI izan = 'please', 'be indebted to', as well as + NOR-NORK izan 'like', 'owe'. These nouns lack the obligatory determiner of arguments and are invisible to Case and agreement. Provided they can still be analysed as selecting a dative argument, the analysis is unchanged. For zor izan, Etxepare and Oyharçabal (2008b) present an example with a nonagreeing dative from the northeastern dialects, in which nonagreeing datives signal nonapplicative datives generated below the theme (discussed below):

(17) a. Baina zuri ere zor natzaizu. (X. Lizardi, Ezkondu ezin ziteken mutila)

b. Jakitatea zor da guzieri, baina lehenik gazteeri. (Etxepare and Oyharcabal 2008) Knowledge is due to everyone, but above all to young people.

7. The dative would create the PCC if moved between the absolutive and $v$, e.g. through the edge of small clause. Apparently it does not in these grammars; but perhaps it does so for speakers who have the pattern in (i).

(i) a. Kepa Mikeli zordun zako b. Berari joaiten / *zordun nako. (MD) 
The constructions invite the following question: what if the small clause of (14) were embedded under an ECM rather than a raising verb, (18) for French? The structure should be immune to the PCC, because it contains ACC/ABS > DAT c-command at the point of $v$-theme Agree. ${ }^{8}$ Postal (1984) indeed reports that there are speakers who find the resulting clitic clusters good in (18), while not permitting them in ditransitives (cf. (46)). However, most speakers do not seem to accept them, perhaps because the prevalence of the PCC has led to a morphological gap, as discussed for natzaio type forms in section 12 (but cf. note 5). For Basque, a good candidate for ECM is the 'enveloping construction' of Rebuschi (1983): could (19)a be transformed to (19)b using such a form as naiozu for the blank? It cannot, but again the reason is perhaps to be sought in the absence of naiozu in the Basque verb paradigm to spell out the syntax (cf. section (2). Such gaps must probably be invoked independently to explain the absence of forms like (salbatu) gaitut to translate Je nous ai sauvé d'une mort certaine fine in English and French (q.v. Rooryck 2006). ${ }^{9}$

(18) Pierre nous lui croit $\left[_{\mathrm{SC}} t_{\text {nous }}\left[_{\mathrm{AP}}\right.\right.$ fidèle $\left.t_{\text {lui }}\right]$, nous autres communistes. (Postal 1984)

$$
\left[_ { \mathrm { SC } } \text { ni } \left[_{\mathrm{AP}} \text { leiall] nauzu } \rightarrow\right.\right. \text { (ni) Kepari leial }
$$

Similar in structure to the small clauses of the preceding constructions would seem to be progressive and other aspectual periphrases that use the NOR(-NORI) paradigm, (20)a (see Ortiz de Urbina 2003a for an overview). Generalizing Laka's (2005) analysis of the progressive, ABS c-commands DAT in (21) because the subject of the aspectual verb originates outside the infinitive containing the dative. It is then expected that there would be no PCC, I(20).

(20) a. gauza baten eskatzen zatzaitzanean (Axular)

b. Isis jainkoa ... Harpokratesi bularra ematen ari zaiona. (EuskaraCorpusa.net)

c. Aholkua Mikeli eman dagokio. "She is advising Mikel." (Ortiz de Urbina 2003a)

d. Bera zuri babak egiten hasi jatzu(*z).

He began cooking the beans for you. (Arregi and Molina-Azaola 2006)

e. Kantatzera noazu bertso bat edo beste.

I am going to sing you one or two verses. (Ortiz de Urbina 2003a)

(21) $\left[(\mathrm{ARI} / \mathrm{EGON} / \mathrm{IBILI} / \ldots) \mathrm{ABS}_{\mathrm{i}}\left[_{\mathrm{INF}} \mathrm{PRO}_{\mathrm{i}} \mathrm{V}\right.\right.$-tzen/tu ... DAT ... $\left.]\right]$

As Ortiz de Urbina (2003a) emphasizes, the nature of dative agreement in these constructions is not obvious. First, it occurs without restructuring for auxiliary selection, unlike in nahi-behar constructions (Ortiz de Urbina 2003b), so we have to posit a semi-clausal boundary transparent to

8. As posited though not shown for Swiss German ditransitives by Albizu (1997), Anagnostopoulou (2003).

9. The same issue arises for a dative displacement grammar, with neri eman nauzu in causatives: beside Trask's 1981 eman arazi nautak we might expected emanarazi naiozu, which certainly some speakers do not accept. 
agreement but not to auxiliary selection. ${ }^{10}$ However, recent research has turned up much agreement crossing even finite clauses, including in Basque (Artiagoitia 2001). Second, dative agreement in the progressive is optional even in dialects where dative agreement is otherwise obligatory. However, that seems attributable to the semi-clausal boundary. A direct parallel occurs in Icelandic, where obligatory nominative agreement becomes optional when an infinitival boundary intervenes (Sigurðsson 1996).

In view of these issues, Ortiz de Urbina suggests that the agreeing dative is introduced by the aspectual itself, comparing Zertan ari zaio "What is she doing to him?" The proposal recalls Rouveret and Vergnaud's (1980) analysis of benefactive datives in French causatives. The faire à causative does not permit the dative internal argument of an unergative to cliticize due to the Specified Subject Condition created by the causee. Thus in (22)a, leur cannot be interpreted as the telephonee. However, the dative clitic itself is available with a benefactive reading here, and (22)b combines it with the in-situ dative argument of téléphoner. To account for these dative clitics in contexts where the arguments of the infinitive cannot cliticize, Rouveret and Vergnaud basegenerate them in the matrix clause.

(22) a. Cela leur fera téléphoner leur fils. (leur = *argument of téléphoner, $\sqrt{\text { benefactive })}$

b. Nous lui avons fait parler Pierre à Marie pendant trois heures.

(Rouveret and Vergnaud 1980)

Generating the dative agreement controller of the aspectual outside the infinitive has consequences to address before preferring it to remote agreement with the infinitive's dative. In (20), dative agreement reflects the argument of the infinitive, not an extra one, so the dative introduced by the auxiliary must relate to the argument of the infinitive by binding/coreference if it is not by remote agreement. Because of Condition C, the infinitive-internal dative must be pro linked to Harpokratesi projected by the aspectual auxiliary, not the other way around, just as in $[(22)$ the dative clitic must be disjoint from the dative argument of the infinitive. It should accordingly be possible for the aspectual to introduce a dative independent of the infinitive, again as in (22), for example Mireni aholkua bere lagunei ematen ari natzaio. These issues remain to be explored.

Even if we retain the analysis (21) for aspectual periphrases, the NOR-NORI aspectuals in them are not constrained by the PCC even in their lexical uses, and those do not so obviously involve ABS > DAT c-command: (23). Worse, (24)-(26) are 1/2:NOR-NORI combinations with datives that resemble the psych-experiencers, possessors, and datives of interest that are often obligatorily applicative datives in Romance (Cuervo 2003) and Basque (Etxepare and Oyharçabal 2008ab, by obligatory agreement in the relevant dialects).

10. Contrast (i). Similarly agreement and auxiliary switch go together in (ii), a different type of restructuring involving mediation of the infinitive itself (Etxepare 2003b). There is no agreement with the infinitive's absolutive in any of these simply because they have their own matrix absolutive, otherwise it occurs, (iii) (cf. Albizu 2000, Etxepare 2003a: 461 for other double-absolutive structures, but cf. Lafitte 2001: 255f.).

(i) aSemeei kotxe berriak erosi behar dizkiet. "I need to buy my children some new cars".

bBerari hurbildu behar natzaio/*diot/??naiz. "I must get close to him." (Ortiz de Urbina 2003b)

(ii) abSaiatu(ko) gara/dizugu [zuri hori ematen]. (Etxepare 2003b: 173)

(iii) aOrain mendiak ikusten hasi dira. "Mountains begin to be seen now." (Ortiz de Urbina 2003c)

b[Nobela beltzak irakurtzea] gustatzen zai(zki)o. (Extepare 2003b: 171) 
(23) galdez nagotzue "I am asking you." (Axular < Ortiz de Urbina 2003a)

(24) zer dela-eta agertuko zatzaizkigu guri...? (John 14:22)

(25) Ni izango natzaio berari aita. (Uriarte, Biblia, Kings II 7:14)

(26) Nori axola gatzaizkio?

b.Gure telebistari bost axola gatzaizkio. (Google)

I can only add the caveat that superficial meaning is a poor guide to structure, as similar thetaroles may be expressed through both applicative and prepositional datives, and in other ways: they seem to her - they strike her - iruditzen zaizkio; bururatu zaio - it occurs to her - it dawns on her (- it hits her-she realizes); il les lui faut - ils lui manquent - faltatzen zaizkio - she needs them; ils sont à elle -- ils lui appartiennent - elles les possède; ella las olvidó - ella se olvidó de ellos -- ella se le olvidaron; il lui incombe/convient de - il est à elle de. Pertinent are the prepositional datives with stative predicates identified in Etxepare and Oyharçabal (2008b), (27), recalling the last pair in this list.

(27) a. Guri da egiazko euskaldunak Euskal Herrian sor-araztea.

It is to us to produce true Basques in the Basque country.

b. Zure etorkizunari gomeni ez diren molde herrestarat...

to the rude manners that are not convenient for your future

(Etxepare and Oyharçabal 2008b)

This brings us to the last NOR-NORI construction considered here, more strikingly problematic than any of the above: reflexive detransitivisation, (28). The acceptability of $1 / 2$ :NOR-NORI forms here is difficult to explain in the measure that their transitives are subject to the PCC, ${ }^{*}$ gomendatu $n$ (a) iote, ${ }^{*}$ emango $g(a)$ izkiete, indicating a DAT > ABS c-command for the applicative transitive $v$ P. On the simplest assumptions, detransitivisation should keep that structure, affecting only the transitive locus $v$ and higher regions.

(28) a. Ni bere nagusiari gomendatu natzaio.

Me he recomendado a su jefe. (Albizu 2000)

b. Otoitz eta hitzaren zerbitzuari emango gatzaizkie.

We will give ourselves to prayer and to the ministry of the word. (Acts 6:4)

There are other hints that the simplest assumptions might not suffice. For plain NOR-NORK transitives, detransitivisation serves both mediopassive and reflexive readings, much as French/Spanish se formations: ikusten dira 'one sees them' or 'they see themselves / each other'. However, only the reflexive reading exists for $1^{\text {st }} / 2^{\text {nd }}$ person objects. The same difference turns up for Romance se as well (D'Alessandro 2004). Oyharçabal and Etxepare (forthc) extend the contrast to detransitivisations of applicative transitives, where the reflexive reading (28) contrasts with the impossibility of the mediopassive one $(30)$.

(29) ??Hortik (ni) ez naiz ikusten.

One does not see me from here. (Ortiz de Urbina 2003c)

(30) * Esperantza dut orduan emaztetzan emanen natzaizula

I hope that then I will be given to you as wife. (Oyharçabal and Etxepare forthc)

Albizu (2000) analyses reflexives and mediopassives in Basque as in $/(31)$ (simplifying to rel- 
evant aspects): both are bivalent, projecting PRO in [Spec, $v \mathrm{P}]$ and the overt absolutive in the object position, and look unaccusative because PRO (essentially) does not get Case so there is no ergative assigned. The two readings arise from the two readings of PRO independently seen in control: if the absolutive raises to c-command PRO, PRO gets an antecedent to which it is coreferential, and thus reflexive, otherwise it is free and thus arbitrary. ${ }^{11}$

(28) a. $\left[\mathrm{PRO}_{\text {arb }} \mathrm{T}\left[_{\mathrm{vP}} t_{\mathrm{PRO}} v_{\mathrm{ABS}}[\mathrm{VP} V \mathrm{O} \cdot \mathrm{ABS}]\right]\right]$

b. O.ABS $\left.T\left[_{v \mathrm{P}} \mathrm{PRO}_{\mathrm{i}} \mathrm{v}_{\mathrm{ABS}}\left[{ }_{\mathrm{VP}} \mathrm{V} t_{\mathrm{O}}\right]\right]\right]$

Let me depart from a somewhat different starting point. D'Alessandro (2004) analyses the restriction on $1^{\text {st }} / 2^{\text {nd }}$ person nominative objects in Italian mediopassives as an instance of the PCC. The null arbitrary agent of the mediopassive is an arbitrary pro projected in [Spec, $v \mathrm{P}]$, where it plays the same role as an applicative dative: it prevents $\mathrm{T}_{\text {Nom }}$-object Agree for person, $(32)$, though it does not itself get the nominative Case of T. Extending this to Basque, we get (33)a, where Caseinert pro in $\left[\mathrm{Spec}, v_{\mathrm{ABS}}\right.$ ] is meant to prevent $v$-ABS person Agree. To that effect, $v_{\mathrm{ABS}}$ is placed in $\mathrm{T}$ prior to its person Agree, so pro is on the $v$-ABS path. This may be due to a principled conflation of functional categories when possible, here because $\mathrm{T}$ does not have a Case to assign conflicting with $v$ 's (Rezac 2008c); or the conflated $T+v$ may be specific to detransitivisations, the Basque equivalent of the Romance se clitic. ${ }^{12}$

(32) Italian mediopassive: $\left[\mathrm{T}_{\mathrm{NOMi}}\left[_{\mathrm{vP}} \operatorname{pro}_{\text {arb }} v_{[-\mathrm{ACC}]}\left[\mathrm{V}\right.\right.\right.$ O. $\left.\left.\left.\mathrm{NOM}_{\mathrm{i}}\right]\right]\right]$

(33) a. Mediopassive (ikusten dira/*zara):

b. Reflexive (ikusten dira/zara):

$$
\begin{aligned}
& {\left[\mathrm{T}_{\text {[-ERG] }}+v_{\mathrm{ABS}}\left[\mathrm{v}_{\mathrm{vP}} \text { pro }_{\text {arb }} t_{v}[\mathrm{~V} \text { O.ABS } \mathrm{A} \text { i]] }\right.\right.} \\
& {\left[\mathrm{T}_{[-\mathrm{ERG}]}+v_{\mathrm{ABS}}\left[{ }_{v \mathrm{P}} \mathrm{EA}^{-A B S_{\mathrm{i}}} t_{v}\left[\mathrm{~V} \text { pro }{ }_{\text {refl-i }}\right]\right]\right]}
\end{aligned}
$$

For reflexive detransitivisations, absence of such a pro would account for the goodness of $1^{\text {st }} / 2^{\text {nd }}$ person objects. One way to proceed is as in $(33) \mathrm{b}$, where the reflexive reading has a Case-inert reflexive pro object bound by the overt agent in $[$ Spec, $v \mathrm{P}]$. Pro is not on the $\mathrm{T}+v$-EA path and so there is no PCC. Adding an applicative layer does not change anything:

(34) a. Med. (eman zaio/*natzaio): $\left[\mathrm{T}+v_{\mathrm{ABS}}{ }_{\mathrm{vP}} \operatorname{pro}_{\mathrm{arb}} t_{\mathrm{v}}[\mathrm{DAT}\right.$ Appl [V O.ABS $\left.\left.\left.\mathrm{i}]\right]\right]\right]$

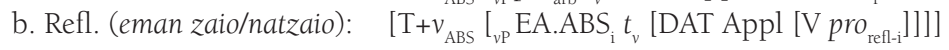

11. Medová (2008: 6.1.2) attributes this analysis to a 1986 handout by R. Kayne, "Participles, agreement, auxiliaries, Se/Si and pro" presented at Princeton U., while Albizu builds on a 1999 ms. by A. Mendikoetxea "Relaciones de interfaz en la Teoría Gramatical: Las construcciones inacusativas" presented at EHU/Gasteiz.

12. By putting $v_{\mathrm{ABS}}$ in $\mathrm{T}$ in detransitivisations (or all unaccusatives?), (33) adopts a key aspect of Albizu and Fernández's (2006) approach to ergativity with $\mathrm{T}_{\mathrm{ABS}}$. It is not necessary to proceed in this manner, but it makes for simpler exposition. The alternative is to keep $v_{\mathrm{ABS}}$ in the $v \mathrm{P}$, and suppose: (i) the derivational mechanics of Rezac $(2003,2006)$ for ergative displacement, whereby $v_{\mathrm{ABS}}$ Agrees with its specifier if it finds no object goal; (ii) pro/PRO is not a goal for Case assignment, permitting (i) in the reflexive, and just like the dative in ditransitives with ergative displacement it has no effect on v's second cycle Agree person with [Spec, $v \mathrm{P}$ ]; (iii) pro/PRO in [Spec, $v \mathrm{P}$ ] in mediopassives creates the PCC either if we assume Baker's (2008) approach to the PCC, so that $v$ can person Agree only with [Spec, $v \mathrm{P}]$, or if we posit that both a $1^{\text {st }} / 2^{\text {nd }}$ person absolutive and an arbitrary (not reflexive) pro/PRO need [+person] Agree and $v$ can only provide it to one. 
(31) and (33) are very similar: both are bivalent, deploy the same elements, and are superficially unaccusative because their silent element is inert for Case. In (33) just like in I(31), the silent element may be taken to be PRO, bound by a c-commanding DP and thus reflexive and free/arbitrary otherwise. The difference between $(31)$ and $(33)$ is that the reflexive-mediopassive difference in the mutual c-command of the overt and silent elements is derived by movement in (31) but basegenerated in (33). In this respect, ('33) is an adoption to Basque of Medovás (2008) proposal for se constructions in Romance, building on the observation that their overt element is accessible to en/ ne-cliticisation in mediopassives but not in reflexives. Here the reason for adopting (33) comes from the PCC: it is harder to have PRO block v-ABS Agree in $(31)$ a but not $(31) b$, considering that in gustatu-type verbs, the theme moves past the higher dative to [Spec, TP] to satisfy the EPP, as in [(31) b (cf. ("8)a), yet the PCC is not thereby obviated (Rezac 2008a; unless by 'absolutive displacement' replacing natzaizu by dizut, evidently not taking place here). ${ }^{13}$

(33) might also be preferable to (31) for the mysterious double absolutive construction available only to reflexives (Albizu 2000, Etxepare 2003a). In mediopassive detransitivisations of applicative transitives, the dative is always retained. So it is also in standard reflexive detransitivisations, where the EA and the direct object are identified and reflected by the overt absolutive argument. However, there also exists a more dialectally limited detransitivisation where the EA and the applied object are identified, and the argument that reflects them surfaces as a second absolutive in addition to the direct object: (35), (36). This extra absolutive is higher than the direct object, because only it can control plural agreement. The existence of this possibility for reflexives is easily derived from the structure in (34)b: it suffices to allow the reflexive pro/PRO be the applied rather than the direct object, parametrisable by its ability to bear the dative assigned in [Spec, ApplP] or by the resources needed to license an extra absolutive as in English double object structures. A mediopassive cannot be derived in this manner, since the EA c-commands [Spec, ApplP] and does not permit a pro/PRO there to have an arbitrary reading.

\section{a. $\sqrt{ } / *$ Etxe berria erosi naiz. Me he comprado casa nueva.}

(36) a. Mikel besoa hautsi da. Mikel broke his arm. b. $\sqrt{ } / *$ Txapela jantzi naiz Me he vestido la boina (Albizu 2000)

b. ?Adiskideak besoa $\left({ }^{*} \mathrm{k}\right)$ hautsi dira. My friends broke an arm each / *their arms.

(Etxepare 2003a)

With (31), double absolutives are more unclear to me. Basque datives do not become absolutive even when there is no absolutive in the structure, for example irudi + $\mathrm{CP}$ where an ergative or absolutive expletive is need to satisfy the EPP (Albizu and Fernández 2006), indeed not even in 'dative displacement' dialects where they participate in $v$ person Agree (Fernández 2001). Perhaps the $v$ of detransitivisations could be held to affect the dative Case assigning potential of Appl so it

13. Albizu's/(31)b is based on evidence opposite en/ne-cliticisation in Romance: the subject of a reflexive detransitivation may be partitive, indicating its origin as an object. Perhaps however the partitive rather picks out the same set of elements as can get absolutive, rather than objects. The present proposal actually permits (31)b, with its problems for the ne/en evidence, if PRO/pro can be bound from a derived position; it would not obviate the PCC. Albizu's proposal in $\$(31)$ might be directly adapted to accounting for person restrictions by exploiting the difference between a dative and (coindexed) PRO intervener. 
introduces a bare argument (cf. Svenonius 2005). ${ }^{14}$

A caveat is in order to conclude. Ortiz de Urbina (2003c) marks (29) as ?? and finds textual counter-examples. Zribi-Hertz (1983), discussing the $1^{\text {st }} / 2^{\text {nd }}$ person restriction for French se-mediopassives, notes that it can be overcome by favouring the point of view of the impersonal agent, (137). The same seems to obtain when the reflexive reading is contextually odd, (138). Such ameliorations need not mean that there is no PCC here; the effect of context might be to permit a metonymous treatment of the $1^{\text {st }} / 2^{\text {nd }}$ person as an object, as happens in (39) (cf. note 2). Or French might be different from Italian where the restriction is due to the PCC (cf. Medová 2008 for Czech). The matter remains to be addressed for Basque.

(37) a. Vous allez voir, je me transporte facilement, je suis la perle des paralytiques.

b. Je me range n'importe où, je me transporte facilement, je vous suis indispensable. (says the luggage, on its packing or in a cartoon)

(Zribi-Hertz 1983: 363-5)

(38) Je me convaincs/*trahis facilement. (Rezac 2008c)

(39) Nous ne nous vendrons jamais. (nous = the speaker's writings) (Sandfelt 1928: 133)

\section{What are agreeing nonapplicative datives?}

Some northeastern varieties of Basque permit nonagreeing dative arguments where others require agreement. Etxepare and Oyharçabal (2008ab) persuasively correlate the agreeing-nonagreeing split with the two different syntactic structures of concern here. Agreeing datives are applied objects introduced above the theme, while nonagreeing ones originate in a prepositional construction below it, as in the English double/prepositional object alternation:

(40) a. Applicative: [EA $v$ [DAT (Appl) $[\mathrm{O}$ V]]]

b. Prepositional: [EA $v[\mathrm{O} \mathrm{V}[(\mathrm{P}) \mathrm{DAT}]]]$

Each structure has its correlates, including the theta-role of the dative: for example, possessors, datives of interest, and psych-experiencers can only avail themselves of the applicative structure and thus must agree in the northeastern dialects. To a first approximation, with the caveats mentioned above, the obligatory agreement picks out the same datives as cause as the PCC effects in NOR-NORI structures, the gustatu type. Similarly for NOR-NORI-NORK structures, the prepositional datives picked out by nonagreement in the northeastern dialects probably corresponds to those whose agreement can be omitted elsewhere to repair the PCC, as in (1): indirect objects but not possessors, for example. So far then, there is a promising convergence of the agreement and PCC lines of evidence.

However, if absence of the PCC for hurbiltzen / mintzatu natzaio identifies their dative as prepositional, how is their dative agreement morphology to be analysed? The same issue arises independently of the PCC for dative such as those of komeni izan 'befit', mintzatu 'talk', or fidatu 'trust': nonagreement identifies them as theta-roles coded by the prepositional structure in Etxepare and

14. Even where the applied object assumes fully the Case/agreement of the direct object of plain transitives, unlike the dative of Basque, it need not be permitted to participate in reflexive detransitizations like the latter; see Farrell (2005: 88) for Halkomelem vs. Baker (2006: 202) for Mohawk. Partially and mysteriously like double absolutives is (i), with both à and participle agreement. Two absolutives also superfically occur in (ii).

(i) Elle s'est offert(\%e) le cadeau à elle-même. (cf. Medová 2008)

(ii) Elkar ikusiko gara bihar. (Lekeitio p. 176) 
Oyharçabal (2008ab), yet in other dialects they do control their obligatory dative agreement and are immune to the PCC. It would seem that here applicative and prepositional datives control the same agreement morphology, including the 'dative flag' as a reflex of the applicative head (q.v. Elordieta 2001).

This problematic observation can be deepened in morphology and extended to syntax. In the Irun-Hondarribia-Pasaia zone, the NOR-NORI morphology is undergoing an assimilation to the NORNORI-NORK type (Fernández 2004): both from the zai(zki)t to the di(it/zki)t type, and further to the (niri) nau (zki/te/ $\varnothing$ ) type if the NOR-NORI-NORK paradigm has itself adopted the NOR-NORK paradigm under "dative displacement" (Fernández 2001, 2004, Rezac 2006, 2008b). As Fernández (2004) points out, both gustatu and hurbildu verb classes are affected, though we have seen that only the former are subject to the PCC. ${ }^{15}$

(41) a. Gustatzen naute. (Fernández 2004)

b. Niri sagarrak erori naute. (Fernández 2004)

c. eldú nauzkí (Irun/Hondarribia 2005)

While the shift from NOR-NORI to NOR-NORI-NORK morphology seems to be an instance of syncretism outside syntax, as Fernández (2004) shows, dative displacement itself has been argued to depend on the applicative structure where the dative is in the range of $v$ Agree, as in the above-cited works. There is a more clearly syntactic correlate grouping agreeing / applicative against nonagreeing / prepositional datives in the northeastern dialects, and for it the dative of hurbildu natzaio groups with agreeing datives. This is Aresti-Linschmann law (Rebuschi 1995). By it, emphatic reflexives of the neure/bere type require an agreeing antecedent (or rather one that would agree in a finite clause). Consider now the dative of verbs like mintzatu 'talk'. In varieties without obligatory dative agreement, its dative does not agree, indicating a prepositional dative. In others it does but does not cause the PCC, leading to the same conclusion. Yet whenever it does agree, including in forms like natzaio, it counts as the antecedent of emphatic reflexive, putting it with applicative datives and against the prepositional ones that do not agree in the first type of dialects. Aresti-Linschmann's Law has been viewed as relying on the applicative structure (Etxepare and Oyharçabal 2008a).

(42) a. ni Joni bere $_{\mathrm{i}^{*} \mathrm{j}}$ semeaz mintzatu natzaio $_{\mathrm{i}}$. b. ni Jonekin haren/*$_{i}$ bere semeaz mintzatu naiz. (Rebuschi 1995: 319)

(43) Neure $_{i}$ iaun maitea, ioan zatzaizkit lurretik... (Axular)

So there are properties of the dative of hurbiltzen natzaio / zaio that group it with applicative datives, despite invisibility to the PCC. The same issues recur in French, with further clues for an analysis. In (45), the dative clitic originates within the AP, as discussed above, yet it licenses a middlefield bare floating quantifier, which requires c-command from an A-position and has been taken to be a distinctive property of applicative datives (Kayne 1975, Anagnostopoulou 2003). Of course, it suffices that at some point during cliticisation, the dative occupies such a position, without this being the position where applicative datives originate and which is relevant in creating the PCC. Indeed, dative clitics that originate in APs retain nonapplicative properties. One is immunity to the

15. In this region, to be sure, all 1/2:NOR-NORI forms have been lost morphologically (section [2), but the PCC contrast of other varieties surfaces in "absolutive displacement", (i) (see Rezac 2008a).

(i) Zu neri gustatzen / *hurbildu nazu. (Manterola 2004) 
PCC for some speakers, discussed above, contrasting (46)a and (46)b. Another is binding. Postal (1984) observes that in (46)a the dative may be coreferential with the matrix subject, indicating the clitic's origin in a binding domain not containing that subject, the small clause SC. ${ }^{16}$

(44) Je leur $\mathrm{i}_{\mathrm{i}}$ ai tou(te)s $\underline{\mathrm{S}}_{\mathrm{i}}$ été $\left[_{\mathrm{SC}} t_{\mathrm{je}}\left[_{\mathrm{AP}}\right.\right.$ fidèle $\left.t_{\text {leur }}\right]$.

(45) a. Elle me lui $_{\mathrm{i} / \mathrm{k}}$ croit $t_{\mathrm{me}}$ attaché $t_{\mathrm{lui}}$ (Postal 1984: 133-5)

b. Elle me lui fera $t_{\text {lui }}$ connaître $t_{\text {me }}$. (Rezac 2008c)

So we have evidence in French of a low origin below the theme for the dative clitic in (46)a, and of a high syntactic position for floating quantifier licesing, the latter but not the former shared with applicative datives. The same ideas can be transferred to hurbildu / mintaztu natzaio. The dative originates below the theme as a prepositional dative, but in dialects with obligatory dative agreement, it raises to where it acquires some of the properties that an applicative dative has, including dative agreement control, visibility for dative displacement, and antecedence of emphatic reflexives, but not interference for the PCC.

Some light, if dim and uneven, is shed on this hypothesis by languages with agreeing applicatives that do not participate in the PCC, such as Abaza. Like Basque, Abaza codes the ergative, absolutive, and applied objects in its agreement complex. However, the absolutive is not subject to the PCC, (47)a. Moreover, Abaza applicative constructions behave differently from those of the type in Baker (1996), including in their free combinability to form multiple applicative structures like (47)b. O'Herin (2001) argues that their distinctive properties follow if the agreement + applicative morphology comes from the incorporation of a low preposition that has agreed with its argument within its own PP, (48). Remarkable support is offered by the alternation of agreeing applicatives with agreeing prepositions in Abaza, (47)c. Rezac (2008b) adds that the analysis explains the absence of the PCC, since the applied object originates in the prepositional construction below the theme.

(46) a. b-[hə-c]-yə-r-ca-t' A2SG.F-[P1PL-COM]-E1PL-carry-FUT1

We will take you with us. (Abaza, O'Herin 2001:

b. $\quad \mathrm{y}-[\mathrm{l} ə-\mathrm{c} ə]_{\mathrm{A}}-[\mathrm{r}-\mathrm{z}]_{\mathrm{B}}-[\mathrm{a}-\mathrm{la}]_{\mathrm{C}}-\mathrm{h}-\mathrm{c̆j}_{\mathrm{j}} \mathrm{pa-t}$

3si-3sf-COM-3p-BEN-3si-INST-1p-do-DYN

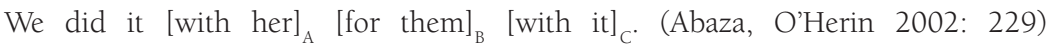

c. sara bilet [wara wəo $_{\mathrm{i}}$-qaz $]$ y- $\sqrt{a}$-s-aw-d

I ticket you 2sm-for 3si-PV-1s-find-DYN

I found the ticket for you. (Abaza, O'Herin 2002: 219)

(47) $v+[\mathrm{P}+\mathrm{AGR}]$

ABS

$\left[_{\mathrm{PP}} t_{\mathrm{P}+\mathrm{AGR}} \mathrm{DP}\right]$

Extended to Basque, $(148)$ would yield a source for the dative agreement + applicative head in natzaio type forms that derives it from a low prepositional dative below the theme yet creates a high

16. This is an oversimplification of complex binding data, but the point holds; see Rezac (2008c). 
position by movement, the mix of properties we want. However, Abaza also casts into relief the shortcomings of this idea. Abaza applicatives occur with both transitives and unaccusative, incurring no PCC in either, and they are not restricted in their mutual combination. Neither is true of Basque. Still, elsewhere there are applicatives invisible to the PCC and combinable with each other yet subject to much greater restrictions than in Abaza, for example Ainu (Shitabani 1990), Djaru (Tsunobi 1981), and Abkhaz (Hewitt 1989) that like Basque allows no multiple applicatives. In Basque also, the prepositional agreeing dative of ( $(48)$ would have to be restricted to unaccusatives, since there are no transitive 1/2:NOR-NORI-NORK combinations. However, there are Basque varieties with such forms, and perhaps reflect a grammar where a prepositional-source agreeing dative combines with transitives: Leizarraga's Lapurdian, studied in Oyharçabal and Etxepare (forthc), and the Zeanuri variety mentioned in Azkue (1925-5(II): §808). A prediction that might be right is that their 1/2:NOR-NORI-NORK forms are restricted to datives analysable as prepositional, for example goals but not possessors. Other Basque varieties have either lost this option in transitives, or - perhaps more interestingly - have generalized the PCC to a set of morphological gaps in the NOR-NORI-NORK paradigm as suggested for NOR-NORI in section 2 .

Finally, it is a stipulation that the agreement/clitics and applicative morphology of the prepositional dative should be identical to that of an applicative dative. Nonetheless, such recycling seems common. In Abaza, the different applicatives use the same agreement morphemes. In Romance varieties in France, the dative and locative clitics often merge: in part elements of different origins have converged ( $y / i<$ Latin adverb hic/ibi, dative pronoun ei/illi, French (l)ui), in part syncretism has extended the range of the result ( $y$ to all datives, Lambrecht 1981, li to locatives in Gascon, Rohlfs 1935), merging the applicative and prepositional structures. The sharing of syntactic elements across partly different structures might contribute to such syncretisms (cf. Kayne 2008 on dative-locative), suggesting that the P of $(48)$ is relevantly identical to the Appl of applicative constructions (Rezac 2008c).

\section{Bibliography}

Adger, D., D. Harbour. 2007. Syntax and syncretisms of the PCC. Syntax 10: 2-37.

Albizu, P. 1997. Generalized PCC. In Theoretical issues on the morphology-syntax interface, ed. M. Uribe-Etxebarria, A. Mendikoetxea, 1-33. Donosti: EHU.

—. 2000. Sobre la distribución sintáctica de las formas finitas del verbo vasco. Ms., EHU.

- 2001. Datibo sintagmen izaera sintaktikoaren inguruan. In On Case and agreement, ed. B. Fernández, P. Albizu, 49-69. Bilbo: EHU.

Albright, A. 2006. Lexical and morphological conditioning of paradigm gaps. Ms., MIT.

Anagnostopoulou, E. 2003. The syntax of ditransitives. The Hague: Mouton de Gruyter.

Andrews, A. D. 1990. Unification of morphological blocking. NLLT 8: 507-557.

Arregi, K., G. Molina-Azaola. 2006. Restructuring in Basque. WCCFL 23: 43-56.

A. Nevins. 2006. Obliteration vs. Impoverishment. U. Penn WPL 13: 1-14.

Artiagoitia, X. 2000. Hatserreak eta parametroak lantzen. Gasteiz: EHU.

—.2001b. Irudiak eta emaileak. Ms., EHU.

Azkue, R. M. de. 1923-5 [1969]. Morfología vasca. Bilbo: La Gran Enciclopedia Vasca.

Baker, M. 1996. The Polysynthesis Parameter. Oxford: Oxford U. Press. 
- 2008. The syntax of agreement and concord. Cambridge: Cambridge U. Press.

Baerman, M., G. Corbett, D. Brown. 2010. Defective paradigms. Oxford: Oxford U. Press.

Boeckx, C. 2000. Quirky Agreement. Studia Linguistica 54: 354-380.

Bonet, E. 1991. Morphology after syntax. Doctoral dissertation, MIT.

Boyé, G., P. Cabredo Hofherr. 2010. Defectiveness as stem suppletion. In Baerman et al.

Cuervo, C. 2003. Datives at large. Doctoral dissertation, MIT.

D’Alessandro, R. 2004. Impersonal si constructions. Doctoral dissertation, U. Stuttgart.

Elordieta, A. 2001. Verb movement and constituent permutation in Basque. Leiden: LOT.

Etxepare, R. 2003a. Valency and argument structure. In Hualde and Ortiz de Urbina.

2003b. Menpeko infinitiboak eta urruneko komunztadura euskaraz. Lapurdum 8: 167-206.

Farrell, P. 2005. Grammatical relations. Oxford: Oxford U. Press.

Fernández, B. 2001. Absolutibo komunztaduradun ergatiboak, absolutibo komunztaduradun datiboak. In On Case and agreement, ed. B. Fernández, P. Albizu, 147-165. Bilbo: EHU.

-. 2004. Gustatzen nau gustatzen dizu. In Euskal gramatika XXI. mendearen atarian, ed. P. Albizu, B. Fernández, 89-112. Gazteiz: Arabako Foru Aldundia.

—. 2006. Licit and illicit ERG-DAT pairings. In Andolin gogoan, ed. B. Fernández, I. Laka, 69-96. Bilbo: EHU.

Hewitt, B. G. 1989. Abkhaz: A structural reference grammar. London: Routledge.

Hualde, J. I., J. Ortiz de Urbina. 2003. Grammar of Basque. Berlin: Walter de Gruyter.

Jelinek, E. 2000. Datives and argument hierarchies. MITWPELFL 1: 51-70.

Kayne, R. 1975. French syntax. Cambridge, Mass.: MIT Press.

Lafitte, P. 2001 [1979]. Grammaire Basque (Navarro-Labourdin littéraire). Donosti: Elkar.

Laka, I. 2000. Thetablind Case. In Arguments and Case, ed. E. Reuland, 103-129. Amsterdam: John Benjamins.

Lambrecht, K. 1981. Topic, antitopic, and verb agreement in non-standard French. Amsterdam: John Benjamins.

Le Roux, P. 1957. Le Verbe breton. Rennes: Librairie Plihon.

Manterola, J. 2004. Datiboaren lekualdatzeaz. Ms., EHU.

Medová, L. 2008. Reflexive clitics in Slavic and Romance. Doctoral dissertation, Princeton.

Oyharçabal B. 2008a. Locational datives and dative agreement in the eastern dialects of Basque. European Dialect Syntax III, Venice, September 2008.

Oyharçabal B. 2008b. Bi datibo egitura ifar-ekialdeko zenbait hizkeratan. Aldaketak, aldaerak, bariazioak euskaran eta euskal testugintzan. Baiona, Dec. 2008.

O’Herin, B. 2001. Abaza applicatives. Language 77: 477-493.

- 2002. Case and agreement in Abaza. Arlington, Texas: SIL.

Ortiz de Urbina, J. 1989. Parameters in the Grammar of Basque. Dordrecht: Foris.

—. 2003a. Periphrastic constructions. In Hualde and Ortiz de Urbina.

—. 2003b. Semiauxiliary verbs. In Hualde and Ortiz de Urbina. 
—. 2003c. Impersonal clauses. In Hualde and Ortiz de Urbina.

Oyharçabal, B., R. Etxepare. forthc. The absence of PCCs in Early Lapurdian..

Postal, P. 1984. French indirect object cliticisation and SSC/BT. Ling Analysis 14: 111-172.

- 1990. French indirect object demotion. In Studies in Relational Grammar 3, ed. P. M. Postal, B. D. Joseph, 104-200. Chicage: U. Chicago Press.

Rebuschi, G. 1983. Structure de l'énoncé en basque. Paris: SELAF.

—. 1995. Weak and strong genitive pronouns in northern Basque. In Towards a history of the Basque language, ed. J. I. Hualde et al. Amsterdam: John Benjamins.

Rezac, M. 2003. The fine structure of cyclic Agree. Syntax 6: 156-182.

—. 2006. Agreement displacement in Basque. Ms., EHU.

—. 2008a. The syntax of eccentric agreement. NLLT 26: 61-106.

- 2008b. Phi-Agree and theta-related Case. In Phi theory: Phi-features across interfaces and modules, ed. D. Harbour et al., 83-129. Oxford: Oxford University Press.

- 2009. On the unifiability of repairs for the Person Case Constraint. In Benat Oyhartzabali Gorazarre. ASJU XLIII, 769-790.

—. 2010. Ineffability through modularity. In Baerman et al.

—. 2011. Phi-features and the modular architecture of language. Dordrecht: Springer.

and M. Jouitteau. in prep. Animacy and the PCC. Ms., CNRS UMR 7023 and 7110.

Rohlfs, G. 1935. Le Gascon. Halle: Niemeyer.

Rooryck, J. 2006. Binding into pronouns. Lingua 116: 1561-1579.

Rouveret, A., J.-R. Vergnaud. 1980. Specifying reference to the subject. Linguistic Inquiry 11: 97-202.

Sandfeld, K. 1928. Syntaxe du français contemporain. I: Les pronoms. Paris: Champion.

Schütze, C. T. 1997. INFL in child and adult language. Doctoral dissertation, MIT.

Sigurðsson, H. 1996. Icelandic finite verb agreement. WP in Scandinavian Syntax 57: 1-46.

Svenonius, P. 2005. Case alternations in the Icelandic passive. Ms., CASTL.

Trask, R. T. 1981. Basque verbal morphology. Iker 1: 285-304.

Tsunoda, T. 1981. Interaction of phonological, grammatical, and semantic factors: An Australian example. Oceanic Linguistics 20: 45-92.

Zribi-Hertz, A. 1983. La construction 'se moyen'. Lingvisticae Investigationes 6: 345-401.

Ahetze: Cabodevilla, J. 1991. Aetzen Uskara. Iruñea: Nafarroako Gobernua.

Antzuola: Larrañaga, J. 1998. Antzuolako hizkera. Antzuolako Udala.

Arrasate: Elortza, J. et al. Arrasateko euskara. Arrasateko Udala.

Basauri: Arretxe, J. 1994. Basauriko euskara. Basauri: Basauriko Udala.

Bergara: Elexpuru, J.M. 1988. Bergarako Euskara. Bergara: UNED.

Bermeo: Egaña'Tar, A. 1984. Bermeoko aditzaren azterketa lorratzak. Bermeo 4: 13-43.

Beskoitze: Duhau, H. 1993. Hasian hasi: Beskoitzeko Euskara. Donibane Lohitzune: Irkus.

Deba: Zuazo, K. 1999. Deba Ibarreko Euskeria. Eibar: Deba ibarreko udalak. 
Eibar: Eibarko Euskara Mintegia. 1998. Eibarko aditza. Eibarko Udala.

Ermua: Aranberri, F. 1996. Ermua eta Eitzako Euskara. Ermuko Udala.

Erronkari: Peña, A. 2005. Erronkariera I: Gramatika. Donostia: Hiria Liburuak S.L.

Forua: Gaminde, I. 1992. Foruko euskararen morfosintaxiaz. Foruko Udala.

Larresoro: Epelde, I. 2003. Larresoroko Euskara. PhD Thesis, UPV/EHU.

Lek: Hualde, J. I., G. and A. Elordieta. 1994. The Basque dialect of Lequeitio. Bilbo: EHU.

Mallabi: Mugarza, P. 2006. Mallabiko euskara. Mallabiko Udala.

Markina: Rollo, W. 1925. The Basque dialect of Marquina. Amsterdam: H. J. Paris.

Maya: N'Diaye, G. 1970. Structure du dialect basque de Maya. Mouton: The Hague.

Oiartzun: Fraile, I., A. Fraile. 1996. Oiartzungo hizkera. Oiartzungo Udala.

Oñati: Badihardugu. 2005. Deba ibarreko aditz-taulak: Oñati.

Ondar: Rotaexte, K. 1977. Estudio estructural del euskera en Ondarroa. Durango: Zugaza.

Otxandio: Burguete, X, I. Gaminde. 1991. Otxandioko Euskaraz. Otxandioko Udala..

Pasaia: Agirretxe, J. L., M. Lersundi, O. Olaetxea. 1998. Pasaiako hizkera. Pasaiako Udala.

Ultzama: Ibarra, O. 1995. Ultzamako hizkera. Iruñea: Nafarroako Gobernua.

Zaldibia: Etxabe, K., L. Garmendia. 2003 Zaldibiako euskara. Zaldibiako Udala.

Zeberio: Etxebarria, J. M. 1996. Zeberio haraneko euskararen azterketa. Bilbo: Deusto.

Zuberoa: U. J. Lüders. 1993. The Souletin verbal complex. München: Lincom. 